\title{
Violências e contemporaneidade
}

\author{
Irme Salete Bonamigo \\ Universidade Regional Comunitária de Chapecó (Unochapecó)
}

\section{Violências e contemporaneidade}

Resumo: Este artigo ${ }^{1}$ parte da discussão do sentido etimológico do termo violência, analisa as suas múltiplas possibilidades de definição e as práticas consideradas violentas na atualidade. A contemporaneidade é compreendida tendo como referência a teoria da sociedade global de riscos, proposta por Ulrich Beck, o que permite conceber as violências como configurações contemporâneas, vinculadas à imprevisibilidade e aos riscos que compõem o mundo atual. Identifica o discurso de segurança emergente como uma possibilidade de mobilizar as pessoas e legitimar práticas de vigilância e controle sociais, constituindo uma estratégia de acesso e manutenção do poder de governar um município, um estado, uma nação. Apresenta algumas proposições teórico-metodológicas para o estudo das violências na contemporaneidade, a partir da pesquisa realizada e fundamentos da sociologia ator-rede.

Palavras-chave: violências, segurança, contemporaneidade, sociologia ator-rede.

\section{Violence and Contemporaneity}

Abstract: This article discusses the etymological meaning of the term violence, analyzes the multiple possibilities of the definition and practices considered violent today. Contemporaneity is understood through a reference to Ulrich Beck's theory of the global society of risks, which allows conceiving violence as contemporaneous configurations, linked to imprevisibility and to the risks that compose the current world. It identifies the emerging discourse of security as a possibility to mobilize people and legitimize practices of vigilance and social control, constituting a strategy of access and maintenance of the power of governing a municipality, state or nation. The paper presents some theoretical-methodological proposals for the study of contemporary violence, based on the study conducted and on the sociology of actor-network.

Key words: violence, security, contemporaneity, sociology of actor-network. 
A tal da violência que parece agir como um espectro ou fantasma, esconde-se ou disseminase, é tratada como uma epidemia, um vírus, um micróbio, ou como um Sujeito onipresente, onisciente, onipotente. Que diabo é esse? O que unifica nesse nome conflitos, crimes e comportamentos tão diferentes? O que nos faz pensar que tudo isso tem um nome só?

Michel Misse

A denominação 'violência' está naturalizada. A mesma palavra é utilizada para referir-se a diversas situações e a diferentes significados, configurandose um processo de generalização e homogeneização do fenômeno. Tem se destacado como um dos grandes temas de discussão do nosso cotidiano. Diariamente, os meios de comunicação apresentam um balanço da violência, com informações sobre as mais recentes vítimas de assaltos, crimes, conflitos, mortes e comportamentos diversos.

No entanto, as violências ${ }^{3}$ urbanas dizem respeito a uma série de eventos vinculados à contemporaneidade, com variadas motivações, contextualizadas em diferentes espaços, o que conduz à necessidade de abranger, nas investigações sobre este tema, a diversidade e a multiplicidade que o compõe.

Desnaturalizar e conhecer o que hoje é denominado como violência foi um dos objetivos da minha pesquisa de doutorado, da qual este artigo é resultante. Para tal, a violência foi constituída como um artefato da pesquisa que conduziu, durante todo o processo, aos seus sentidos múltiplos e singulares, nos espaços de sua circulação.

Este artigo, partindo da discussão do sentido etimológico do termo, pretende abordar as implicações relacionadas ao seu uso e os diversos sentidos que comporta na contemporaneidade, associados às transformações que o caracterizam.

\section{A categoria violência}

A palavra origina-se do latim violentia que remete a vis e significa caráter violento ou bravio, força, vigor, potência, emprego de força física. Significa também quantidade, abundância, essência e força em ação. Para Michaud (1989), a etimologia do termo evidencia a idéia de uma força não qualificada que se torna violência apenas quando passa da medida, quando perturba uma ordem, quando rompe acordos e regras que ordenam relações.

A análise do sentido etimológico coloca em relevo que é a percepção do limite que vai caracterizar um ato como violento e essa percepção varia histórica e culturalmente. Portanto, o termo não pode ser definido independentemente de critérios e de pontos de vista, os quais podem ser institucionais, jurídicos, sociais e até pessoais. Não se pode deixar de fora 0 que é eminentemente normativo e não existe uma abordagem objetiva que consiga pôr entre parênteses todas as normas. Querer engessar a expressão em uma definição fixa e simples significa reduzi-la e deixar de compreender as singularidades que caracterizam diferentes povos, as transformações e especificidades históricas. Há, portanto, possibilidade da existência de inúmeras formas de violência relacionadas às inúmeras situações e espécies de normas estabelecidas.

Michaud (1989) aponta que a noção violência possui um aspecto performático: a pronúncia implica uma ação, pois the atribuir valor significa começar a agir. Assim, caracterizar um comportamento, uma atitude, uma situação como violentos significa imputar-lhes um valor que provoca uma atuação, como a denúncia ou a acusação. Logo, longe de ser uma expressão neutra ou descritiva, ela está carregada de valores negativos ou positivos, vinculados à idéia de transgressão. Ela pode ser celebrada se considerada libertadora, ou denunciada pelos efeitos e insegurança que gera. Hoje, os discursos políticos e a preocupação da 'opinião pública', espelhada pela mídia, apreendem qualquer desordem como uma violência que ameaça as regras sociais. Outra característica performática no emprego dessa palavra, apontada por Misse (2006, p. 10), diz respeito a como se usa e contra quem se usa essa expressão: "Raramente alguém diz de si mesmo ser violento [...]. Violento é sempre o outro, aquele a quem aplicamos a designação."

É importante ressaltar que a categoria violência comporta múltiplos significados na contemporaneidade. Portanto, não podemos utilizar o termo no singular, pois: "[...] não existe violência, mas violências, múltiplas, plurais, em diferentes graus de visibilidade, de abstra- 
ção e de definição de suas alteridades" (MISSE, 1999 , p. 38, grifo do autor).

\section{Práticas consideradas violentas na contem- poraneidade}

Se violência é, hoje, uma expressão utilizada para referir diversas situações, diferentes significados e diz respeito a múltiplos eventos com motivações e contextualizações várias, torna-se necessário perguntar: há algo em comum entre as diferentes práticas que têm sido identificadas como violentas na contemporaneidade?

O Centro Internacional de Investigação e Informação para a Paz (CIIIP, 2002), vinculado à Universidade para a Paz das Nações Unidas identificou práticas que considera violentas, agrupando-as em cinco tipos básicos, como a seguir.

a) Violência coletiva: é produzida "[...] quando a sociedade coletivamente, ou por meio de grupos significativamente importantes, participa ativa e declaradamente da violência direta" (CIIIP, 2002, p. 33). Como exemplo, temos as práticas resultantes de uma guerra.

b) Violência institucional ou estatal: refere-se a práticas resultantes de instituições legitimadas para o uso da força. Abrange as tecnologias de destruição e os processos armamentistas.

c) Violência estrutural: é instituída dentro da estrutura social. Inclui as práticas, comumente denominadas, de desigualdade social. Abarca tanto os recursos distribuídos desigualmente quanto o poder desigual de decisão sobre essa distribuição.

d) Violência cultural: refere-se ao tipo exercido de forma individual ou coletiva através da utilização da diferença para inferiorizar ou desconhecer a identidade do outro. As práticas de discriminação contra indivíduos ou grupos, as violências de gênero e as ações contra o meio ambiente, ${ }^{4}$ são exemplos.

e) Violência individual: trata-se daquela que se manifesta de um modo interpesssoal. São incluídos aqui " $[\ldots . .$.$] os chamados fenômenos de$ segurança civil, tais como as violências anômica, doméstica e contra as crianças" (CIIIP, 2002, p. 34), os fenômenos da violência comum (não organizada) e a organizada, como, por exemplo, o narcotráfico.

Para analisar possíveis similaridades entre as definições anteriores e o agrupamento de diferentes práticas, denominadas violentas, recorro à noção proposta por Michaud (1989). Segundo o autor, de uma forma geral, são consideradas violentas situações de interação, quando
[...] um ou vários atores agem de maneira direta ou indireta, maciça ou esparsa, causando danos a uma ou a mais pessoas em graus variáveis, seja em sua integridade física, seja em sua integridade moral, em suas posses, ou em suas participações simbólicas e culturais (MICHAUD, 1989, p. 10-11).

A definição de Michaud contribui para examinar que há em comum entre as práticas destacadas a ocorrência de um dano, que pode envolver indivíduos, grupos, organizações e Estados e podem implicar corpos, sentimentos, posses, distribuição de recursos, direitos, gênero, etnia, ética, poder, dentre outros elementos que compõem práticas definidas como violência.

Mas, se considerarmos que os significados referidos pela designação dano remetem a ferimento, ofensa, estrago, prejuízo e podem envolver configurações diversas, então, novamente retornamos para a impossibilidade de separar a palavra do contexto onde é proferida, pois implica referenciar valores e normas e considerar as singularidades de cada situação.

Por exemplo, as concepções de ato violento atualmente são amplas; contudo, tradicionalmente eram vinculadas à existência de dano físico. As modificações em nossa percepção e sensibilidade possibilitam hoje abranger novos tipos de violências que antes não eram considerados, como: discriminação por cor, sexo, idade, etnia, religião, escolha sexual; situações de constrangimento, exclusão ou humilhação. Para Waiselfissz (2000), hoje este termo se encontra ligado ao conceito de alteridade, nas formas e mecanismos pelos quais a sociedade convive com as diferenças.

Longe de defender uma postura relativista no que diz respeito a princípios e regras que envolvam limites no processo de convivência social, busco enfatizar a relevância de que, no processo de investigação do tema, os significados e as práticas relacionados à categoria não sejam determinados a priori, mas apreendidos nos coletivos onde se desenvolve a pesquisa. Até porque, cada vez mais, as práticas consideradas violentas são criminalizadas, com novas leis que buscam enquadrá-las, como a Lei n. 9.459, de 13 de maio de 1997, que modifica a redação sobre os crimes resultantes de preconceito de raça ou de cor (BRASIL, 2007a), ou a Lei n. 11.340, de 7 de agosto de 2006, que cria mecanismos para coibir a violência doméstica e familiar contra a mulher (BRASIL, 2007b).

Chesnais (1981, p. 18), ao contrário dos discursos contemporâneos que alardeiam o crescimento da violência ${ }^{5}$ nos últimos anos, afirma que a intolerância relacionada às suas práticas é resultado, na verdade, da sua diminuição, pois "[...] quanto mais um fenômeno desagradável diminui, mais aquilo que resta se torna insuportável." $\mathrm{O}$ autor, baseado em uma pesquisa na Europa que abrange 200 anos $^{6}$, afirma que o número de homicídios diminuiu: há dois séculos, havia nos países europeus um índice de 60 a 80 homicídios por 100 
mil habitantes que diminuiu para três por 100 mil. Ele analisa que os fatores responsáveis por esta queda foram as lutas dos trabalhadores, que conseguiram melhores condições de vida, a diminuição das desigualdades sociais, a criação de instituições fortes, sobretudo a educação formal. Para o autor, quando um demógrafo ou um historiador afirma que a violência cresce progressivamente, ele se refere não ao aumento contínuo da grande criminalidade, mas da pequena e média delinqüência.

No entanto, Wieviorka (2004) ressalta que a história do século 20, aquela das guerras, dos genocídios e de outros massacres de massa, convida-nos a resistir à imagem de um recuo generalizado da violência no mundo contemporâneo, pois ela aparece e se estende no seio de inúmeros espaços, constituída como um recurso, um meio de alcançar fins, e, ao lado das identidades culturais e das religiões, acompanha aspirações muitas vezes sem limites.

[...] a violência substitui o conflito, as identidades culturais suscitam tensões e medos, Deus está de volta em todo o planeta, e não somente com o Islam, o terrorismo, a guerra se sobrepõe à negociação e acentua cada dia mais o déficit do político à escala do mundo, transformando a ideologia do 'choque das civilizações' em propriedade auto-realizadora (WIEVIORKA, 2004, p. 214, grifo do autor). ${ }^{7}$

As análises internacionais de Chesnais e Wieviorka, mesmo diferenciando-se parcialmente de preocupações e práticas predominantes no Brasil, possibilitam detectar certas conexões com discursos sobre violências que circulam no país.

\section{Contemporaneidade e violências}

A contemporaneidade é aqui compreendida com base na teoria da sociedade global de riscos, proposta por Ulrich Beck, como 'segunda modernidade' ou 'modernização reflexiva'. Apresenta características muito peculiares, que resultam em mudanças importantes na vida cotidiana e impõem a necessidade de produzir novos referenciais e análises originais para compreender esse novo contexto.
Beck (1997) considera que a controvérsia entre modernistas e pós-modernistas tornou-se pouco produtiva e propõe um terceiro caminho para o entendimento dos fenômenos da contemporaneidade: a 'modernização reflexiva'.

O autor diferencia entre uma primeira e uma segunda modernidade. A primeira, é denominada como modernidade simples ou industrial e caracterizada nos termos de "[...] uma sociedade estatal e nacional, estruturas coletivas, pleno emprego, rápida industrialização, exploração da natureza não "visível'" (BECK, 2000, p. 1). A segunda ${ }^{8}$, ou modernidade reflexiva, distingue a contemporaneidade e implica em um processo [...] no qual são postas em questão, tornando-se objeto de 'reflexão', as assunções fundamentais, as insuficiências e as antinomias da primeira modernidade" (BECK, 2000, p. 1).

Uma das teses fundamentais da teoria da modernização reflexiva ressalta que quanto mais avança a modernização das sociedades, mais as bases da sociedade industrial ficam dissolvidas, modificadas e ameaçadas.

\begin{abstract}
Assim, em virtude de seu inerente dinamismo, a sociedade moderna está acabando com suas formações de classe, camadas sociais, ocupação, papéis dos sexos, família nuclear, agricultura, setores industriais e, é claro, também com os pré-requisitos e as formas do progresso técnico-econômico. Esse novo estágio, em que o progresso pode se transformar em autodestruição, em que um tipo de modernização destrói outro e o modifica, é o que eu chamo de etapa da modernização reflexiva (BECK, 1997, p. 12).
\end{abstract}

O autor esclarece que, primeiro, não é a crise, mas as vitórias do capitalismo que produzem a nova forma social. Segundo, que é a modernização normal e a modernização adicional que estão dissolvendo os contornos da sociedade industrial e não a luta de classes. Pontua, ainda, que, para conceber a modernização como um processo de inovação autônoma, é necessário contar, por um lado, com a obsolescência da sociedade industrial e, por outro, com a emergência da 'sociedade de risco'.

O autor denomina 'sociedade de risco' a "[...] uma fase de desenvolvimento da sociedade moderna, em que os riscos sociais, políticos, econômicos e individuais tendem, cada vez mais, a escapar das 
instituições para o controle e a proteção da sociedade industrial" (BECK, 1997, p. 15). Identifica duas fases como componentes desse processo. Na primeira fase, os efeitos e as auto-ameaças são produzidos, mas não chegam a se tornar questões públicas ou foco de conflitos políticos. Nesse estágio, $\mathrm{o}$ autoconceito de sociedade industrial predomina, multiplicando ou legitimando as ameaças produzidas com a justificativa de que constituem 'riscos residuais'. A segunda fase emerge quando os perigos da sociedade industrial dominam os debates e conflitos públicos e privados. As instituições da sociedade industrial tornam-se produtoras e legitimadoras das ameaças que não conseguem controlar. Alguns aspectos da sociedade industrial passam a ser social e politicamente problemáticos, pois:

Por um lado, a sociedade ainda toma decisões e realiza ações segundo o padrão da velha sociedade industrial, mas, por outro, as organizações de interesse, o sistema judicial e a política são obscurecidas por debates e conflitos que se originam do dinamismo da sociedade de risco (BECK, 1997, p. 16).

Com base nessas fases, o autor afirma que o conceito de modernização reflexiva não significa reflexão, mas autoconfrontação, e completa que a passagem do período industrial para o período do risco da modernidade acontece de forma indesejada, despercebida e compulsiva, seguindo o dinamismo autônomo da modernização e o padrão dos 'efeitos colaterais latentes'. As certezas da sociedade industrial $^{9}$ que dominam o pensamento e as práticas das pessoas e das instituições geram a composição da sociedade de risco.

\begin{abstract}
A sociedade de risco não é uma opção que se pode escolher ou rejeitar no decorrer de disputas políticas. Ela surge na continuidade dos processos de modernização autônoma, que são cegos e surdos a seus próprios efeitos e ameaças. De maneira cumulativa e latente, estes últimos produzem ameaças que questionam e finalmente destroem as bases da sociedade industrial (BECK, 1997, p. 16).
\end{abstract}

Beck diferencia a confrontação das bases de modernização com as suas conseqüências, da autoreflexão sobre a modernização, resultante do conhecimento e da cientificação. A modernização reflexiva implica autoconfrontação com os efeitos da sociedade de risco que não podem ser tratados e assimilados no sistema da sociedade industrial. $\mathrm{O}$ fato de, mais tarde, em um segundo estágio, poder vir a se tornar objeto de reflexão (pública, política e científica) "[...] não deve obscurecer o mecanismo não refletido e quase autônomo da transição: é exatamente a abstração que produz e pro- porciona realidade à sociedade de risco" (BECK, 1997, p. 16-17).

Com a emergência da 'sociedade de risco' há uma mudança no que se refere aos conflitos predominantes. A sociedade industrial clássica foi caracterizada pelos conflitos da distribuição de bens: renda, emprego e seguro social. Na 'sociedade de risco', estas tensões são encobertas pelos conflitos de distribuição dos malefícios, ou seja, pelos conflitos de responsabilidade distributiva. A discussão gira em torno do modo como os riscos que acompanham a produção de bens podem ser evitados, controlados, distribuídos e legitimados. O autor cita, como exemplo, os conflitos referentes à pesquisa genética, a ameaça ao ambiente e a miséria crescente fora da sociedade industrial ocidental.

Um conflito fundamental da 'sociedade de risco', levantado pelo autor, relaciona-se "[...] aos antagonismos ideológicos, culturais, econômicos e políticos que se agrupam em torno da dicotomia seguro/inseguro e tentam se distinguir uns dos outros" (BECK, 1997, p. 23). Uma possibilidade de enfrentálo seria através do controle racional e instrumental, recorrendo à tecnologia, ao mercado, ao governo, ou seja, com base em referenciais da sociedade industrial, a partir de um eixo teórico linear. Outra possibilidade seria repensar e buscar uma nova maneira de agir, que aceite e afirme a ambivalência, com conseqüências de longo alcance para todas as áreas da ação social, a partir de um eixo reflexivo. Conforme o autor,

Somente na redefinição do presente os limites da velha ordem explodem e as ambivalências irredutíveis - o novo distúrbio da civilização de risco - aparecem abertamente. Desse modo, há cada vez menos formas sociais (padrões de atuações) produzindo ordens de ligação e ficções de segurança importantes para a ação. Esta crise de ficções de segurança da sociedade industrial implica que as oportunidades e compulsões para a ação se abram, e entre elas uma deve permanentemente decidir, sem qualquer reivindicação de soluções definitivas - um critério pelo qual viver e agir na incerteza torna-se uma espécie de experiência básica. Quem pode fazer e aprender isso, como e por que, ou por que não, torna-se por sua vez uma pergunta biográfica e política fundamental da época atual (BECK, 1997, p. 23).

Como situar a questão das violências na 'sociedade de risco'? Que análises podem ser tecidas com relação aos perigos que, por vezes, rondam a nossa integridade física e moral, a integridade de nossos bens e a nossa participação simbólica e cultural, no contexto da contemporaneidade? É o que me proponho a discutir no tópico a seguir. 


\section{Violências e insegurança social}

A categoria violência pode ser analisada conjuntamente com a categoria insegurança. Segundo Bauman (2003), a imersão em um mundo fluido e imprevisível, pleno de desregulamentação, flexibilidade, incerteza e competitividade, gera insegurança. No entanto, cada um de nós vive a ansiedade, fruto dessa insegurança, como problema privado, por conta própria, como se fosse resultante de falhas pessoais, como se fosse um desafio ao nosso 'saber fazer' e à nossa habilidade. Posso, aqui, aproximar as análises de Beck (1997, 2000, 2003) com a de Bauman (2003, p. 129), quando afirma que na contemporaneidade somos chamados a "[...] buscar soluções biográficas para contradições sistêmicas; procuramos a salvação individual de problemas compartilhados." No entanto, essa tática não dá o resultado desejado porque não elimina a insegurança. A dependência que temos de nosso saber e recursos individuais produz a insegurança da qual buscamos fugir.

Tendemos a procurar proteção como remédio para o desconforto da insegurança e para manter "[...] a integridade de nosso corpo e de todas suas extensões e trincheiras avançadas - nossa casa, nossas posses, nosso bairro" (BAUMAN, 2003, p. 130). Esse procedimento nos leva a suspeitar dos outros a nossa volta, principalmente dos estranhos, que representam o não-previsto. $\mathrm{O}$ estranho significa a corporificação da falta de proteção e da insegurança que ameaça a nossa vida. De forma ambivalente, a presença de estranhos gera também conforto, pois os temores difusos e dispersos, difíceis de nomear, tornam-se alvos visíveis, focos que representam o perigo. E se há alvos visíveis, alguma coisa pode ser feita.

A dificuldade maior é a preocupação com ameaças que não se pode nomear e enfrentar. Não podemos situar com precisão as fontes de insegurança, pois estão ocultas e não aparecem nos mapas. No entanto, os estranhos que passam pelas ruas são bem visíveis, estão ao nosso alcance, temos a possibilidade de afastá-los.

O resultado disso é lermos, vermos e ouvirmos pouco sobre a insegurança que sentimos e muito sobre o que ameaça as nossas ruas, as nossas casas e os nossos corpos:

A demanda de livrar a comida que comemos dos ingredientes prejudiciais e potencialmente letais que pode conter e a demanda de livrar as ruas por onde andamos dos estranhos inescrutáveis e também potencialmente letais são as que mais se ouvem quando se fala das maneiras de melhorar a vida, e também as que parecem as mais críveis, em verdade evidentes. Agir de maneira a não atender a essas demandas é o que preferimos chamar de cri- me, cuja punição desejamos, e quanto mais severa, melhor (BAUMAN, 2003, p. 130-131).

Para o autor, a percepção pública está baseada na crença de que a vida urbana está contaminada de perigos e que a medida mais urgente para restaurar a segurança é livrar as ruas dos ostensivos e ameaçadores estranhos. Esta crença aparece como verdade, evidente por si mesma, não precisando de provas e nem admitindo discussões.

Michaud (1989) considera que a noção de violência, assim como as noções de caos, de desordem radical e de transgressão, envolve a idéia de uma distância em relação às normas e às regras, que coordenam as situações normais ou legais, e contém a ameaça do imprevisível. A violência introduz o desregramento e o caos em um mundo que se deseja estável e regular. Essa imprevisibilidade também é encontrada na idéia de insegurança.

O sentimento da insegurança, que se encontra no coração das discussões sobre o aumento da violência, raramente repousa sobre a experiência direta da violência. Ele corresponde à crença, fundada ou não, de que tudo pode acontecer, de que devemos esperar tudo, ou ainda de que não podemos ter certeza de nada nos comportamentos cotidianos. Aqui, novamente, imprevisibilidade, caos e violência estão juntos (MICHAUD, 1989, p. 13).

Para Diógenes (1998), a imprevisibilidade das práticas vinculadas à violência que atravessam a vida social tem gerado nos indivíduos uma profunda insegurança, uma sensação de desamparo que parece afligir certezas e racionalidades já alcançadas no mundo da ciência. Anteriormente, na sociedade industrial, a violência era concebida pelas Ciências Sociais como vinda de fora, produzindo ruptura com relação à ordem e ao equilíbrio, considerados próprios dos acontecimentos. Nesse sentido, estudos buscaram a sua eliminação e, com isso, produziram dicotomias como centro/periferia, ordem/desordem, normalidade/desvio.

Desenvolve-se uma série de argumentações que, quase sempre, levam a supor a existência de 'ações violentas' que seriam possivelmente controladas com a 'eliminação ou contenção do sujeito praticante' de atos de violentos. Ao ser pensada como um ato isolado, mesmo configurando-se de forma mais ampla a partir da visão de um cenário propício às práticas de violência, tende-se a deixar de perceber a violência como uma extensiva rede fenomenológica. (DIÓGENES, 1998, p. 78, grifo nosso).

Torna-se necessário, então, produzir análises a partir de novos referenciais que levem em conta este 
novo contexto. Beck (2000) sugere que devemos procurar construir, em meio às contradições e rupturas, linhas de coerência e de continuidade. Propõe, ainda, que busquemos respostas radicais aos riscos e desafios produzidos pela modernidade, a partir do desenvolvimento de novas opções, destacando que eles podem mobilizar novas energias sociais e políticas. Para Diógenes (1998), é necessário potencializar uma visão multidimensional da questão, no sentido de manter a variedade, a diversidade e a multiplicidade dos vários aspectos que a compõe.

As práticas de violência são fundadas na incerteza e no acaso, elas são essencialmente fragmentárias, tendo, por tais características, mobilizado teorizações duais, compartimentalizadas e estigmatizantes. Esse caráter dividido, que pontua o imaginário da violência não deixa de ser uma resistência à percepção da mesma como uma ocorrência de 'dentro da vida social', articulada à sua intrincada rede de acontecimentos (DIÓGENES, 1998, p. 91, grifo do autor).

É necessário, ainda, considerar que a vida social não se constitui em um processo homogêneo, no qual a sociedade, como unidade, circunscreve e produz atores linearmente, mas um processo heterogêneo, onde "[...] a negociação da realidade, a partir das diferenças, é conseqüência de interações sociais sempre heterogêneas e com potencial de conflito" (VELHO, 1996, p. 11).

Assim, a multidão "[...] pode prometer prazer, mas também anunciar perigo, então deter o encontro antes que ele mergulhe além da superfície é o mais comum dos estratagemas" (BAUMAN, 2003, p. 132). Dessa forma, à medida que aumenta a diversidade da multidão urbana, aumenta, também, a suspeita e as razões para o nosso medo. E esse medo pode ser projetado, como vimos, nos estranhos e utilizado para condenar a vida urbana por ser perigosa em razão da diversidade.

\section{Violências, sentimento de insegurança e política}

Freqüentemente, as mesmas vozes que se levantam para denunciar as violências e solicitar segurança para o cidadão clamam por ordem e por controle. Segundo Chesnais (1981), a política se nutre da insegurança porque ela lhe confere autoridade e legitimidade. O discurso sobre segurança é carregado de ambigüidade, pois, apoiado no consenso implícito da sua necessidade fundamental, busca justificar o aumento do controle social, a repressão e, ainda, camuflar perdas de liberdades conquistadas. Para o autor, a exploração do sentimento de insegurança é inseparável das preocupações eleitorais e envolve a direita e a esquerda.

O tema da segurança desperta os instintos mais profundos, dentre os quais o instinto de conservação. Jogando sobre os medos inconscientes, atiça a veia quente da propriedade dos bens e da pessoa, último refúgio da identidade nacional, esse discurso solicita os reflexos, unitários e conservadores, de defesa coletiva (CHESNAIS, 1981, p. 20). ${ }^{10}$

Desta forma, o discurso de segurança, ao atrair e mobilizar as pessoas e ao legitimar práticas de vigilância e controle sociais ${ }^{11}$, constitui uma estratégia de acesso e manutenção do poder de governar um município, um estado, uma nação.

Um exemplo desse tipo de prática, no Brasil, são os programas adotados para combater a criminalidade em muitas campanhas, denominados de Tolerância Zero ${ }^{12}$. Segundo Soares (2002, p. 227), estas campanhas:

[...] freqüentemente fora de contexto e manipuladas para servir aos propósitos oportunistas do candidato - o famoso bordão 'tolerância zero' é o principal exemplo -, as interpretações que se consolidam sobre os resultados da política de segurança de Nova York podem vir a se tornar armas eleitorais importantes [...].

Portanto, é importante ficarmos atentos aos dispositivos de segurança, empregados para 'combater' as violências, e as estratégias de controle, que estão se delineando na contemporaneidade. Esses dispositivos e essas estratégias podem mascarar práticas e discursos de exploração do sentimento de insegurança e medo, vinculados a preocupações eleitorais e à busca de autoridade e legitimidade identificadas por Chesnais.

Violências na contemporaneidade: proposições teórico-metodológicas com base na sociologia ator-rede

O estudo realizado em Chapecó (BONAMIGO, 2007), com base na discussão exposta neste artigo e em fundamentos teórico-metodológicos da sociologia ator-rede ${ }^{13}$ e da teoria da sociedade global de riscos, compôs alguns procedimentos singulares na forma de conceber as violências e conduzir a pesquisa, com desdobramentos que serão relatados a seguir, os quais podem vir a contribuir com novos estudos sobre o assunto na contemporaneidade.

No lugar de tomar uma definição de violência $a$ priori para relacioná-la ao empírico, a pesquisa optou por uma determinada forma de compreendê-la: não como ponto de partida, mas como ponto de chegada. 
Como resultado final de um processo que envolve 'mediadores' em sua fabricação e que, além das práticas consideradas violentas, aborda os processos de 'tradução' 14 da categoria, os processos de 'inscrição' 15 dessas práticas e as estratégias de gestão e controle. Nesse sentido, a investigação abrangeu diferentes aspectos relacionados ao tema em foco, a partir do trabalho de campo, que resultou na descrição:

a) das estatísticas oficiais que inscreviam práticas violentas;

b) da emergência da categoria violência no processo de constituição de coletivos que a tomaram como foco;

c) das estratégias de gestão das violências que implicaram em tecnologias de vigilância e controle;

d) do acompanhamento de um evento violento; e

e) da análise dos efeitos da veiculação de práticas violentas pela mídia.

A ênfase na não dissociação dos significados traduzidos pela categoria violência dos valores e das normas dos coletivos investigados, que acompanhou as 'traduções' e todo processo de investigação, teve como efeito a valorização das singularidades na descrição dos eventos estudados. Cito, mais especificamente, a realização da etnografia de um evento considerado violento, narrado a partir de pequenas histórias, de cenas e diálogos, que tornou perceptível uma trama de redes, que disputam e fazem alianças, conectando uma diversidade de atores que as fabricam cotidianamente.

A identificação das dicotomias produzidas nos estudos levou a escolha de referenciais teóricometodológicos que buscaram tangenciar divisões como: local/global, dentro/fora, normalidade/desvio, ordem/desordem, centro/periferia, bem/mal e levar em conta o novo cenário político-social, de forma a não reduzir a complexidade, mas manter a variedade, a diversidade e a multiplicidade que compõem as violências. A sociologia ator-rede destacou-se neste processo, pois possibilitou descrever as associações heterogêneas, seus mecanismos de consolidação ou transformação, de forma a não reduzir nem a um ator ${ }^{16}$, nem a uma rede ${ }^{17}$. As propriedades metodológicas no emprego da noção de 'rede', proposta por Latour (1996), permitiu contornar as dicotomias longe/perto (há elementos próximos que não estão conectados na rede, podendo ser considerados remotos e há elementos que parecem distantes, mas podem ser atraídos); micro/macro (não precisamos decidir entre um ponto de vista local ou global, mas analisar a intensidade da conexão); e dentro/fora (na rede não há um dentro e um fora separados por uma demarcação, o limite que se estabelece é se a rede permite ou não uma conexão estável entre os elementos). Deste modo, foi possível evitar hierarquizar posições e vínculos e centrar a pesquisa nas conexões que se estabeleciam entre os elementos heterogêneos que compunham as redes tecidas em torno da violência em Chapecó.

A abrangência das mudanças que caracterizam a contemporaneidade permitiu uma atitude atenta para a apreensão da mídia como uma instância de subjetivação coletiva ${ }^{18}$, para a identificação de novos atores e de novas respostas frente à exacerbação do sentimento de insegurança, como as novas tecnologias de vigilância e controle ${ }^{19}$ que compõem estratégias de gestão da violência e o aumento de empresas privadas que vendem 'segurança', ou, ainda, a delegação dos efeitos de uma rede a um ator (o ‘outro', o estranho), que passa então a personificar o 'mal'.

\section{Referências}

BAUMAN, Z. Comunidade: a busca por segurança no mundo atual. Rio de Janeiro: Jorge Zahar Editor, 2003.

BATISTA, V. M. O medo na cidade do Rio de Janeiro. In: VILHENA, J.; CASTRO, R. V.; ZAMORA, M. H. A cidade $e$ as formas de viver. Rio de Janeiro: Editora Museu da República, 2005.p. 45-55.

BECK, U. A reinvenção da política: rumo a uma teoria da modernização reflexiva. In: BECK, U.; GIDDENS, A.; LASCH, S. Modernização reflexiva: política, tradição e estética na ordem social moderna. São Paulo: Editora Unesp, 1997.p. 45-69.

A sociedade global de risco: uma discussão entre Ulrich Beck e Danilo Zolo. Tradução Selvino J. Assmann, 2000. Disponível em: <http://www.cfh.ufsc.br/ wfil/ ulrich.htm>. Acesso em: 6 jul. 2003.

Liberdade ou capitalismo: Ulrich Beck conversa com Johannes Willms. São Paulo: Unesp, 2003.

BONAMIGO, I. S. Violências na contemporaniedade: etnografia de redes sociotécnicas na cidade de Chapecó (SC), 2007. Tese (Doutorado em Psicologia Social) Universidade do Estado do Rio de Janeiro (UERJ), Rio de Janeiro, 2007.

BRASIL. Lei n. 9.459 de 13 de maio de 1997. Altera os art. $1^{\circ}$ e 20 da Lei n. 7.716, 5 de janeiro de 1989, que define os crimes resultantes de preconceito de raça ou de cor, e acrescenta parágrafo no art. 140 do Decreto-lei e 2.848, de 7 de dezembro de 1940. Disponível em: <http:// www81.dataprev.gov.br/sislex/paginas/42/1997/9459.htm>. Acesso em: 13 nov. 2007a.

. Lei Maria da Penha, Lei Federal n. 11.340, de 07 de agosto de 2006, dispõe sobre a criação de mecanismos para coibir a violência doméstica e familiar contra a mulher e dá 
outras providências. Brasília: Ministério da Justiça, 2007. Disponível em: <http://www.planalto.gov.br/CCIVIL/ Ato2004-2006/2006/Lei/L11340.htm>.Acesso em: 13 nov. 2007b.

CHESNAIS, J. Histoire de la violence: en occident de 1800 à nos jours. Paris: Éditions Robert Laffont, AS, 1981.

CENTRO INTERNACIONAL DE INVESTIGAÇÃO E INFORMAÇÃO PARA A PAZ. O estado da paz e a evolução da violência. Campinas: Editora da Unicamp, 2002.

COSTA, A. T. M. Entre a lei e a ordem: violência e reforma nas polícias do Rio de Janeiro. Rio de Janeiro: Editora FGV, 2004.

DIÓGENES, G. Cartografias da cultura e da violência: gangues, galeras e o movimento hip hop. São Paulo: Annablume, 1998.

LATOUR, B. On Actor-Network Theory: a Few Clarifications. Soziale Welt, [S.1.], v. 47, n. 4, p. 369-381, 1996. . A esperança de Pandora. Bauru: Edusc, 2001.

MICHAUD, Y. A violência. Tradução L. Garcia. São Paulo: Editora Ática, 1989.

MISSE, M. Malandros, marginais e vagabundos \& a acumulação social da violência no Rio de Janeiro. Rio de Janeiro, 1999. Tese (Doutorado em Sociologia) - Instituto Universitário de Pesquisas do Rio de Janeiro (Iuperj), Rio de Janeiro, 1999.

Crime e violência no Brasil contemporâneo. Rio de Janeiro: Editora Lúmen Júris, 2006.

SOARES, L. E. O enigma de Nova York. In: OLIVEIRA, N. V. (Org.). Insegurança pública. São Paulo: Nova Alexandria, 2002. p. 227-237.

VELHO, G. Violência, reciprocidade e desigualdade. In: VELHO, G.; ALVITO, M. Cidadania e violência. Rio de Janeiro: UFRJ/FGV, 1996. p. 10-24.

WAISELFISZ, J. Mapa da violência II: os jovens do Brasil. Brasília: Unesco, 2000.

WIEVIORKA, M. La violence: voix et regards. Paris: Éditions Balland, 2004.

\section{Notas}

1 Este artigo foi escrito a partir das pesquisas para a tese de doutorado Violências na contemporaneidade: etnografias de redes sociotécnicas na cidade de Chapecó, Santa Catarina, realizadas no período de 2004 a 2007, contando com auxilio financeiro do CNPq (bolsa de doutorado), CAPES (bolsa de doutorado no exterior) e PCDTU-Unochapecó, e aprovada pela Comissão de Ética em Pesquisa da UERJ (COEP), documento n. 004/2007.

2 Utilizei aqui as aspas para referir-me à forma predominante como a palavra violência tem sido utilizada na contemporaneidade e problematizar a idéia de essência remetida pelo termo, principalmente quando precedido pelo artigo definido 'a' ou pela preposição 'da' (a violência, da violência).

3 Utilizo violências no plural para dar ênfase às múltiplas possibilidades de definição que o termo comporta.

4 Anaturezaé reconhecida como sujeito pelo CIIIP, por isso as ações contra o meio ambiente são consideradas como violência cultural.

5 Chesnais (1981) considera a existência de várias concepções de violência, mas propõe que as mesmas sejam hierarquizadas. Para o autor, o único referente empírico do conceito é a violência física, estando excluídas a moral ou simbólica e a econômica (atentados à propriedade, ou que derivam em privações de ordem econômica).

6 A partirde 1800.

7 Tradução nossa.

8 Segundo Beck(2003,p. 20), não se deve conceber a segunda modernidade no sentido de uma nova periodização, uma época totalmente nova que rompe com tudo o que constituiu a primeira modernidade. $\mathrm{O}$ autor afirma que a diferença entre elas “[...] pressupõe uma comunhão de 'modernidades' que deve ser determinada, apreendida, desenvolvida, investigada e conquistada transnacionalmente, no confronto das experiências e projetos de modernização da periferia e do centro, asiáticas, africanas, chinesas, sul-americanas e do Atlântico Norte. Significa, pois, estabelecer uma diferença entre continuidades e ruptura."

9 Oautor cita como exemplo de certezas da sociedade industrial o consenso para o progresso e a abstração dos efeitos e riscos ecológicos.

10 Tradução nossa.

11 Sobre a discussão do medo como indutor e justificador de políticas autoritárias de controle social, ver Batista (2004).

12 Historicamente a expressão Tolerância Zero surgiu vinculada à gestão de prefeito de Nova York, Rodolph Giuliani, eleito em 1993, que com uma plataforma centrada nos problemas 
de segurança pública, junto com o comissário da polícia WilliamBratton, implementou uma política “[...] que enfatizava a repressão aos delitos contra a qualidade de vida, tais como vandalismos, pichamentos, badernas nas ruas, pequenos furtos etc."'(COSTA, 2004, p. 162).

13 A sociologia ator-rede, mais conhecida como teoria ator-rede, situa-se no campo da sociologia das ciências, que se constituiu, como o próprio nome indica, voltada para o estudo das ciências. No entanto, cunhou um modo de conceber e investigar o mundo que ultrapassa o estudo das práticas científicas, possibilitando analisar outros fenômenos que configuram a contemporaneidade, como as violências. Há muitos autores vinculados a estaárea do conhecimento, destacando-se, dentre eles, Bruno Latour, Michel Callon e John Law.

14 Também denominada de translação. "Em suas conotações lingüística e material refere-se a todos os deslocamentos por entre outros atores cuja mediação é indispensável à ocorrência de qualquer ação. Em lugar de uma rígida oposição entre contexto e conteúdo, as cadeias de translação referemse ao trabalho graças ao qual atores modificam, deslocam e transladam seus vários e contraditórios interesses" (LATOUR, 2001,p. 356).

15 Inscrição é o “[...] termo geral referente a todos os tipos de transformação que materializam uma entidade num signo, num arquivo, num documento, num pedaço de papel, num traço"(LATOUR, 2001,p. 350).

16 Este termo designa qualquer pessoa, instituição ou coisa que tenha agência, que produza efeito na 'rede'.

17 O conceito de rede tem sua origem na topologia e se identifica como uma totalidade aberta capaz de crescer para todos os lados e direções, sendo seu único elemento constitutivo o nó.A rede deve ser compreendida como base em uma lógica das conexões e não das superfícies.

18 Noção fundamentada em Guattari(1992).

19 Foi analisado, em especial, o projeto de instalação de câmeras de monitoramento no centro de Chapecó.

\section{Irme Salete Bonamigo}

Doutora pelo Programa de Pós-Graduação em Psicologia Social da Universidade do Estado do Rio de Janeiro (UERJ)

Professora da Universidade Regional Comunitária de Chapecó (Unochapecó)

Pesquisadora do Programa Integrado de Pesquisa em Políticas Públicas e Cidadania da Unochapecó

\section{Unochapecó}

Centro de Ciências Humanas e Sociais

Avenida Senador Attílio Fontana, 591-E
Bairro Efapi, Caixa Postal 1141

Chapecó - Santa Catarina

CEP: 89809-000 